\title{
Between Tinseltown and Sophiatown: The Double Temporality of Popular Culture in the Autobiographical Cultural Memory of Bloke Modisane and Miriam Makeba*
}

\section{Kgomotso Masemola}

\author{
Summary \\ Prompted by Paul Gilroy's question as to how active remembrance in black \\ expressive culture is associated with a distinctive and disjunctive temporality (1993: \\ 212), this article brings to view divided autobiographical subjectivities through the \\ problematic, if double, temporality of Bloke Modisane's Blame Me on History (1963) \\ and Miriam Makeba's Makeba: My Story (1988) such as they are framed between \\ popular culture and figures of memory that straddle Tinseltown and Sophiatown. It \\ does so by referring to these two prominent Sophiatown figures' preoccupation with \\ voyaging - discursively through figures of memory and bodiographically - in \\ performative Hollywood en route to exile in the geopolitical West. The two autobiographical \\ texts that record each moment of the memoric and material journeys - entries and exits - \\ effectively bear witness to rhizomatic alliances that are foregrounded by Hollywood-mediated \\ agential discourses of performativity. The paper concludes that the signifying time of \\ Modisane's and Makeba's self-representation is doubled by temporal and spatial deixes of \\ both Tinseltown and Sophiatown in general and the margins of reconstructive memory and \\ spectatorship of cinematic popular culture in particular.
}

\section{Opsomming}

Aangespoor deur Paul Gilroy (1993: 212) se vraag hoe aktiewe herinnering in swart ekspressiewe kultuur met 'n kenmerkende en ontwrigtende temporaliteit verband hou, lig hierdie artikel verdeelde outobiografiese subjektiwiteite uit deur middel van die problematiese dog tweeledige temporaliteit van Bloke Modisane se Blame Me on History (1963) en Miriam Makeba se Makeba: My Story (1988) soos dit saamgevoeg word tussen populêre kultuur en figure wat voortleef in die herinnering aan sowel Hollywood as Sophiatown. Daar word gekyk na hierdie twee vooraanstaande Sophiatown-figure se preokkupasie met reise - diskursief deur figure uit die geheue, en bodiografies deur middel van optredes in Hollywood en route na ballingskap in die geopolitiese Weste. Die twee outobiografiese tekste bevat 'n beskrywing van

\footnotetext{
*To cite this article: Kgomotso Michael Masemola (2011): Between Tinseltown and Sophiatown: The Double Temporality of Popular Culture in the Autobiographical Cultural Memory of Bloke Modisane and Miriam Makeba, Journal of Literary Studies, 27:1, 1-27
} 
elke moment van die fisiese reise asook die herinneringe - toetredes en uittredes en getuig op doeltreffende wyse van risomatiese alliansies wat deur middel van die vertoningsdiskoerse van Hollywood op die voorgrond gebring word. Die artikel kom tot die gevolgtrekking dat die aanduidende tyd van Modisane en Makeba se selfverteenwoordiging verdubbel word deur die temporele en ruimtelike gebruik van deïktiese verwysings na beide Hollywood en Sophiatown in die algemeen en die marges van rekonstruktiewe geheue en toeskouerskap van kinematiese populêre kultuur in die besonder.

Testimony is the genre of the subaltern giving witness to oppression ... (Autobiography too, of course, could involve two players: I and me, assumed subject assuming object.)

(Spivak 1998: 7)

Moving from the premise that Sophiatown's popular culture of the 1950s was not so much autochthonous as it was decidedly in touch with its Tinseltown "outside", this paper fixes the deixes of performance of selfidentity on the bodiographic canvas of (trans)cultural memory. It harnesses the body-at-stake to what Sarah Nuttall frames as "bodiographic" when she makes bold to delineate processes of the embodied self, such as the body in relation to others or in exile, from experience of the body in its "fully anatomical dimension - as a body in parts, with its sensory organs" (2002: 27). Writing shaped on the anvil of the latter mode underscores, by definition, the bodiographic aspect. Bloke Modisane in his Blame Me on History (1963) does not limit the meaning of his experience to the symbolism of the body as object of the apartheid socius's injunctions and illicit desire or similar discursive moves but foregrounds the anatomical dimension, too, as he recalls the experience of entry into the darkness of both unpredictable settings and debauched existence in the cinematic idiom of film noir:1 "Our bodies were stimulated .... The muscles of the nerves stretched to cracking" (1963: 263).2 Accordingly, this article also mobilises the concept of "reconstructive spectatorship"3 of Hollywood film text-and-context, understood in relation

1. Bronfen (2004: 103-116) redefines tragedy generally to include the pessimism attending the decadence, betrayal, corruption and death resulting from inhabiting the darkness that formed the setting of film noir in the 1950s.

2. All subsequent references to Blame Me on History (Modisane 1963) are indicated by page number(s) only.

3. Acknowledging her debt to Henry Louis Gates, Jr, whose work on black entry into public discourses became useful for her formulation of this analytical category, Jacqueline Stewart reveals the negotiated reconstructive 
to cultural memory's self-reflexive mode of actuality, "whereby each contemporary context puts the objectivized meaning into its own perspective" (Assman 1995: 130). Evincing the latter mode of cultural memory, Bloke recognises blackness as a handicap (p. 88) from which he momentarily escapes when he loses himself in the darkness of cinema (p. 171). Popular culture then is not only expressive of either Tinseltown or Sophiatown but, in the main, problematises the temporality of cultural memory in autobiography. In drawing a link between "reconstructive spectatorship" of Hollywood film text-and-context - especially but not exclusively of film and cultural memory's self-reflexive mode of actuality, I aver that double temporality arises when the self is recognisably split in the "double time" of transculturative reconfiguration attending Hollywood-mediated autobiographical narrative, where the articulation of intersubjectivity in autobiography goes beyond the positive problematisation of self-representation. Rhizomatic alliances are thus established, particularly where Bloke Modisane sees himself as a product of Hollywood influence, of Tinsel morality and technicolour dreams (p. 172), and remembers his past by connecting to such figures of memory as the Durango Kid (p. 8), Spencer Tracy and Ronald Colman (p. 169) and the Simon Templar figure of "the Saint" ( $p$. 166).

In its analysis, this paper also attaches importance to Fredric Jameson's observation that the double temporality of Deleuzean virtuality is traceable to Jean-Paul Sartre's Transcendence of the Ego, thus acknowledging existentialism's achievement in its "demographic plebeianization" of subjectivity as "we experience the body through our experience of the world and of other people" (Jameson 2003: 710). The campaign against the centred subject, according to Fredric Jameson, is a central theme of Deleuzean philosophy which, he notes, "acknowledges the priority of Sartre's early Transcendence of the Ego" (2003: 710). Jameson's point emphatically vindicates, amongst other things, an appropriation of Deleuze in explaining the Sartrean thrust of Sophiatown and Tinseltown figure Miriam Makeba's multiplicity qua "self-saving" as enmeshed in the double temporality of ontological "selfing" in Makeba: My Story (1988).4 In Makeba's autobiography, discursive ontology is mapped through traces of memorialised flashes of dramatic generation and renewal, township streets and theatre screens. The memory of cinema is connected to the experience of birth and, in this sense, underscores rebirth and its double temporality at the level of spectatorship and resultant community steward

process of audiences and consumers of movies whereby "black viewers could reconstitute themselves as viewing subjects in the face of a racially exclusionary institution and social order" (2003: 661).

4. All subsequent references to Makeba: My Story (Makeba 1988) are indicated by page number(s) only. 
ship. No sooner does Miriam Makeba explain the painful circumstances leading to her birth, as she kicks her mother inside the womb during difficult labour, than she explains the joys of cinema that led to her own pregnancy at seventeen:

Gooli takes me to the movies. It is a theater for blacks. We sit on the balcony, and his great big hand holds mine. The movies we see come from Hollywood. We can identify with the American blacks because they are servants like we are. But they are the lucky ones because of where they live, and every African wants to go to America, because it is the land of opportunity. The official press will not tell us these things, but we learn that black people can make something of themselves in America. Although it is very hard to do, it is not impossible like it is here. We hear of blacks who have achieved this and that: Marcus Garvey and Booker T Washington. Right up on the screen we see Lena Horne, Duke Ellington and Ella Fitzgerald. I rest my cheek on Gooli's broad shoulder and dream what the life of a big American singer must be like.

$$
\text { (p. 25; my italics) }
$$

Makeba's theatre brings black American achievers Marcus Garvey and Booker T Washington to life, and she adds jazz musicians to the Black Atlantic archive from which she draws images almost as an afterthought that contemporises that Hollywood archive to her own aspirations to freedom and stardom. Figures of memory - the black and white faces who left traces - drawn from this Hollywood archive - are scripted into the demands of selfing and becoming. At the height of her stardom, in 1962, Makeba goes on to sing for delegates of the Trustees Committee of the United Nations General Assembly in New York. The following year sees her quest for freedom articulated in her speech in an address to the United Nations Special Committee on Apartheid (p. 111).

One cold night in New York in 1959, Miriam Makeba felt very lonely but fortunately found company in a book given to her by Langston Hughes when he came to see her (p. 91). As she read one of Hughes's poems, "Alone", she understood there and then the Afro-American is just as much lonely and afraid, without ontological security, without national belonging in America, but always expressing transnational becoming in relation to Africa. The ironic sense of belonging in that shared loneliness allows her to identify with Afro-American struggles in the Black Atlantic assemblage while recognising the particularity of her situation. Plebeianisation becomes popular culture's condition of belonging: scripted in both the silver screen and the Afro-American cultural script are openings for plural mitigation of dolorous remembrance. The lines from this "Alone" poem by Hughes were to be a refrain whenever she felt the pain of being "outside", especially when her visa was refused by the South African consulate at a time she was supposed to attend her mother's funeral in South Africa: 
BETWEEN TINSELTOWN AND SOPHIATOWN: THE DOUBLE TEMPORALITY ...

We cry among the skyscrapers

As our ancestors

Cried among the palms in Africa

Because we are alone,

It is night and we're afraid.

(Hughes quoted in Makeba 1988: 91)

As Hughes's poem yokes together the African past to the dilemmas of the present, Makeba's immersion into the politics of ontological security translates into her direct involvement in the American civil rights movement.

This is nowhere better exemplified than in her performance, with Harry Belafonte, at a rally in Atlanta for Dr Martin Luther King, Jr, after which show she spoke to Dr King and his wife, only for Makeba to be part of a televised protest of a restaurant that refused to admit black people according to its Jim Crow racism (p. 100). This was her initiation into Black Atlantic struggles that recognise parallels between Jim Crow segregation and apartheid. Subsequent to this and many efforts involving African countries like Kenya and Ethiopia, Makeba was invited by the United Nations Special Committee on Apartheid to address it. She took that platform to call for a complete boycott of South Africa: "The person Miriam Makeba is no longer just a singer to them. I am a symbol of my oppressed people" (p. 113). Here is a transmogrification from a singer to what Zodwa Motsa aptly describes as "a mass or group hero" (2009: 10). In one sense, Makeba's reinvention in the United States gives occasion to recall Sam Raditlhalo's observation that it (reinvention) "cannot be accomplished through the shedding of an identity" (2009: 44). In another, Makeba's conflation of performance and ostensibly political performativity gives content to the illuminating observation made by Paul Gilroy:

The power of music in developing black struggles by communicating information, organising consciousness, and testing out or deploying the forms of subjectivity which are required by political agency, whether individual or collective, defensive or transformational, demands attention to this expressive culture and its distinctive moral basis.

(Gilroy 1993: 36)

A movement from singer to advocate was anticipated and given meaning by a poem that became a refrain that best expressed the connection between the Afro-American civil rights movement and Makeba's abiding interest in Africa. The poem "Alone" is a figure of memory recalled in the mode of potentiality, repeating the experience of being alone in the eternal return such that she is a sole proxy of South Africa's blacks. Paradoxically, being alone here confers an opportunity rather than a crisis. Being "outside" means exploring the recesses of belonging in the elsewhere, and of articulating a double subjectivity that transculturates figures of memory in one of many a translational site of enunciation. Importantly, Makeba's 
journey to faraway places, according to her cultural memory, was initially set in motion by the ancestral spirit Madlavezulu in a voice that came from her mother: "You will leave South Africa. You will go on a long journey, and you will never come back" (p. 70). At the culmination of the long journey Langston Hughes's poem adds to the polyvocality of Makeba's subjectivity, and so expands the horizon of belonging simultaneously to South Africa and the Black Atlantic through emblematic birth and renewal, each repeated eternally through cultural memory and popular culture. On the one hand, the Prologue to Makeba's text returns, in its transatlantic circulations, to cycles of time that "explain, reinterpret, criticize, censure, control, surpass, and receive hypoleptically" the writing tradition of autobiography: "[F]or us, birth plunges us into a pool in which the waters of past, present and future swirl around together" (p. 2), thus departing from the orthodox chronological delineation of the autobiographical Self's travails into a singular temporality. On the other hand, the opening chapter of Modisane's Blame Me on History features not only the symbolic and material death of Sophiatown but the phenomenological limits of the expression of the self in the local edifice of local culture: "Something in me died, a piece of me died, with the dying of Sophiatown" (p. 5); yet, more than that, it is not the self-reflexive reinterpretation of Sophiatown's death into that of "a piece of him" that can be controlled by way of cultural memory or its Hollywood figures such as the Durango Kid (p. 8), Spencer Tracy and Ronald Colman (p. 169) and such reconstructed icons. Looming large above these, perhaps predisposing Bloke to them, is the need for a paradoxical expression of what he says is "the desire to lose myself" ( $p$. $169)$ in order to save himself from a death like his father's:

The line between fantasy and reality becomes less and less distinct; I cannot tell my friends from my enemies, everything is fading into dust. As the coffin of my father with my name on it had disappeared into the dust. I am frightened by the eternity of endlessness; I hate long journeys, death terrifies me.

Thus, by incorporating fantasy elements of Hollywood popular culture into a regime of self-saving, Bloke Modisane straddles the line between fantasy and reality in an autobiographical "selfing" process that readily acknowledges the double temporality of reality and fantasy, life and death, racial rejection and acceptance, in what easily could have been transference dimensions; further than that, that negotiated - if problematic - regime is a flight that inheres in radical form of spectatorship based on mobility or what Jacqueline Stewart, borrowing from Guilliana Bruno, designates as transito: "many levels of desire as inscribed in both physical and mental motion, including notions of traversing, transitions, transitory states, and erotic circulation" (Stewart 2003: 668). Modisane's desire to save himself by 
losing himself in cinema confirms Stewart's argument that the many layers of desire, fantasy and interpretation of Hollywood films are symptomatic of "a desire for exhilarating circulation" that "can only manifest itself as violent acts, a run from the law, and illicit fantasies within the walls of the neighbourhood movie palace" (Stewart 2003: 669).

It is significant that Bloke Modisane, a contemporary of Miriam Makeba and colleague of Lewis Nkosi and Es'kia Mphahlele at Drum magazine during the Sophiatown heydays, published an autobiography much earlier in 1963 in which he declares: "I had been concerned, primarily with the salvation of Bloke Modisane ..." (p. 170), and so recognising, upon reflection, the ontological split of being into "l" and "Me" or, differently put, a continually dividing subjectivity. In a similar context, the recognisable split of existential self-saving is deeply felt in Miriam Makeba's contemplation of her life, in the aftermath of the death of a daughter who lost her mind during their exile in Guinea:

Mostly, just the fact that I am there at all, that I have survived, is testimony enough that there is resistance toward Pretoria. Maybe a thousand people at a time see me and learn things. It is not much, but it's the best I can do. This is the way I will defeat the great evil, and this is the way I will save myself.

Makeba's agency in exile in the West African country of Guinea involves teaching others in the African diaspora as she performs and speaks out against racism. Such agency is based on a rhizomatic connection between "Mama Africa" the performer of song and Miriam the advocate against apartheid overseas. That connection not only reflects the relationship between the Being-in-Itself and the Being-for-Itself but also explains why when she lived in Hollywood, film icon Marlon Brando tells Miriam Makeba that she has a "split personality", that she is a songstress and "lioness" because of her status as a performer, on the one hand, and advocate against apartheid, on the other (p. 114). However, her presence in Hollywood is a culmination of dropping her name "Zenzile" for "Miriam" in her self-saving, her becoming-Ella Fitzgerald in the darkness of cinema that brought Hollywood to black South Africans (p. 25).

Comparatively speaking, this holds even greater significance in that the "I" in My Story and Blame Me on History finds expression in different modes, each of which is consistent with Sartre's exposition on the futility of "unifying and individualizing the role of the P" (Sartre 1957: 40).5 Whereas at the level of structure it is possible to discern slippery shifts underscored by the double temporality of a concomitant narrative of reverie, this article

5. Without oversimplifying the expostulation, it would seem to me that Sartre's delineation of the I of reflected consciousness, the I of reflective consciousness and the transcendental I in many ways reflects his discussions of the conditions of Being-in-Itself, Being-for-Itself and Being-for-Others. 
deals with the question as to whether the shifts and double temporality are discernible in Modisane's Blame Me on History and Makeba's My Story. To address this requires that we note, at the outset, that there is no reverie to underscore the shifts in the representational time of these autobiographies. Taking a step beyond Mark Sanders's emphasis on intertextuality (1994: 52) in the reading of Modisane's autobiographical narrative, where in the development of a new ethics of reading his short stories are considered to demonstrate his lack of belonging in either black or white worlds, thus situating him between the two worlds, and demonstrating that it is a site of becoming, I will add that the cinematic archive of autobiographical cultural memory is a redoubtable counterpart to popular culture.

Although it is quite clear that Modisane's Blame Me on History and Makeba's My Story at points share a Sophiatown setting, especially when Modisane directly refers to Makeba in Chapters Nine, Twelve and Fifteen of his autobiography (pp. 117, 177, 283-284) what here demands investigation is whether shifts from the written to the cinematic archive in Modisane's autobiography, or even from the oral to the typographical in Makeba: My Story, can be taken to be the logical extension of the double temporality of ontological positions of Being-in-Itself and Being-for-Others. 6 Are these shifts indicative of nomadic lines of flight between and across an autobiographical assemblage? I argue that these nomadic flights of the autobiographical subject run between the self and its extension in a multiplicity. In Blame Me on History, the death of Modisane's father, notably not his namesake until an inscription error on his coffin, prompts and foreshadows a "freakish" anti-death/counter-thanatological process of self-saving/selfaffirmation in writing, "which is an assumption that if I am a freak it should not be interpreted as a failure of their education for a Caliban, but a miscalculation of history" (p. 179).

In Blame Me on History there is a counterpoint to the miscalculation of history, deftly registered in the use of popular culture and cultural memory as a continuity between the representational temporality of South Africa and America's Hollywood "reality", or rather, between historical temporality and fictional non-temporality. This counterpoint lends itself to Bloke's attempts at gaining acceptance in the white world of South Africa, and in humanity, whilst insisting that he is black (p. 140). Using Sartrean terms, I would say the value of black is the lack in relation to which the For-Itself determines being as a lack. A heroism becomes necessary to address that black "lack".

6. Although Being-in-Itself, Being-for-Itself and Being-for-Others signify an objective and all-embracing being, the in-itself differs from the for-itself to the extent that the former is a plenitude whereas the latter is a new dimension of being in which the self exists as an object for others. In Blame Me on History there is a memoric continuity between the representational temporality of South Africa and America's Hollywood "reality", or rather, between historical temporality and fictional non-temporality. 
In Makeba's My Story, the death of Miriam's daughter Bongi as a consequence of losing her mind in exile prompts Miriam to resolve that in order to "avenge her death and the deaths of so many of my family I must continue to speak out against the racism and murder that makes bloody and foul my home" (p. 245). The call to decisive action aims to supersede the amount of resistance offered by apartheid objects to the projects of the ForItself, that is, beyond becoming-Ella Fitzgerald and/or Lena Horne as seen on the silver screen (p. 25) into an activist. In Blame Me on History it is the death of Bloke's father that jolts him into a form of Simon Templar heroism - the birth of the Bloke figure - as he acts on the lack arising out of being black in South Africa and selectively acts out the carefree lifestyle of "The Saint" (p. 166).

With Makeba it is remembering life - an anti-thanatological drive - that lets her trace differential histories of people she has encountered as intertwined with her subjectivity in a double temporality of past and present, memory and celluloid, home and Hollywood: "I close my eyes and the past surrounds me. It is today. The faces - so many - are alive" (p. 2). Here arises an opportunity to be part of an assemblage that, according to Deleuze, calls forth a sympathetic co-functioning "across ages, sexes and reigns different natures. Thus, the assemblage's only unity is that of cofunctioning: it is a symbiosis, a 'sympathy"' (Deleuze \& Parnet 1987: 69). From interaction, Makeba might be familiar with the faces of Marlon Brando, President Kennedy, Sidney Poitier, Nina Simone off-screen, but Bloke's becoming rests on familiarity with movies from which he gleans a lot for his becoming in the black-and-white world into which he could not find his belonging. Alive to the fact that "he is resentfully called a Situation, something not belonging to either but tactfully situated between white oppression and white rebellion" (p. 94), his hope for co-functioning between himself and the worlds that reject him starts with his counter-rejection of morality:

I cannot invest in success, there is no guarantee that tomorrow I shall walk down the street, my nostrils following the perfume of a beautiful woman; the possibility of walking out of the air and falling into a grave is far more persuasive. I have preserved for me a freedom from morality, surrender myself to the lower freedoms: the freedom of all the vices; and since, according to Western civilization's system of beliefs, savagery is black and promiscuity a heathen indulgence - and heathendom is black - I am persuaded into believing that this is the standard expected of me. Western civilization has failed to develop in me its steadying influence, but it has developed me to a state where I have cultivated what Nimrod Mkele has described as a bird-of-passage morality.

I argue here that the freedom from morality is neither the sum total of many a dictum from Omar Khayyám and the Marquis de Sade, as Bloke alleges 
(pp. 206-207), nor a faithful representation of Nimrod Mkele's philosophical ruminations on resolving the condition of being and non-belonging for a highly mobile "Situation" personality, as it were. I aver instead that the licentiousness inspired by Khayyám and the transitory nature of interracial sexual circulation are in a large measure influenced by the tragic condition of corruption, moral decay and illicit fantasies of popular culture as expressed in film noir, such as they are drawn from the cinematic archive of the 1950s. In fact, a quick symptomatic reading of one of the short stories, "The Dignity of Begging", as well as Lewis Nkosi's earlier comments on Modisane's Blame Me on History, will show that it is possible to discern how Hollywood movies provide the figures of memory for Bloke. For instance, Nkosi notes that Modisane's writing "can be as pretentious as his shadow boxing as a militant African nationalist", further decrying Bloke's showy but incorrect lexical items of choice in a specific instance where he states that "African business is a fiscal enterprise" in what Nkosi sees as a liking for the word "fiscal" (1964: 55).

Nkosi is correct, no doubt - to the extent that he elects to underemphasise the fact that Modisane has an intellectual reputation to protect against the odds of being less academically educated or certificated and celebrated like Nkosi and Mphahlele or Nimrod Mkele. He is acutely aware of the highbrow discussions of the middle-class intellectual with whom he identified and associated. The quest for being cultured led him to "read, as Dylan Thomas says, 'all this time with my eyes hanging out'" (p. 251). Most of all, he is, I must add, forever drawing from a vast quarry ranging from Hegel's critique of slave morality to Shakespeare's representation of Venetian society (p. 168), from the journalistic tradition to the silver screen. By his own admission, and given the way in which he sees himself as a product of Hollywood influence of tinsel morality and technicolour dreams (p. 172), there is even more didactic value to spectatorship than the simple fact that he "was a cinema fan" (p. 133).

It is against this background that it is here instructive to turn to his summative expostulation of "The Dignity of Begging" in the course of mapping himself into history, especially taking note of the paradigmatic selections that inform his turn of phrase. For example: "To the handicap of being black I added physical deformity, investing my character with a double indemnity, then confronted him with the realisation of his condition" (p. 88). Surely a "double affliction" would have been apposite? Yet he elects to churn out, almost to a point of malapropism, "double indemnity". The latter expression is, in fact, borrowed from the title of a movie which became popular in the 1940s. It is important to note here that Billy Wilder's Double Indemnity (1944) is the archetypal film noir movie upon which Bronfen bases the tragic condition of the decadent decade following World War II (Bronfen 2004: 104). This is not a coincidence without significance: the intersubjectivity displayed in the bodiographic circulations among faces and objects of illicit desire in both Double Indemnity and Bloke's life raises 
questions as it enhances and confirms through the co-functioning out of both mutual necessity and Deleuzean sympathy. Conversely, the attention to the positionality of "different natures" - beyond the transference dimension - of father and (deceased) son/textual narrative and reverie as evidenced in The Wanderers, of (deceased) father and son/textual narrative and film (in Bloke Modisane's Blame Me on History), subject and object, male storyteller and female story-scribe/oral narrative and orthographic-typographic tradition (in My Story), confirms the self-reflexivity of autobiographical cultural memory: "It is self-reflexive in that it draws on itself to explain, distinguish, reinterpret, criticize, censure, control, surpass, and receive hypoleptically" (Assman 1995: 130).

At one moment, immediately after Bloke has got married to Fiki, he realises the full implications of being confined to marriage and contemplates running away from it all. He decides to stay, surviving by pretending and forgetting until frustration gets the better of him. It is impossible, within the confinement of marriage, to experience the transitory states of erotic circulation: "But there was sanctuary in cinema, and even though I was segregated in the Indian-owned cinemas I managed to lose myself into the darkness, and in the dark I could not see my hand" (p. 171). What he could see were movies with which he interacted as a reconstructive spectator, finding both solace and sanctuary in the cinema. Sanders notices compensation in this solace:

The rods of encroaching night and the gloom of the cinema are cathexes which compensate, albeit with a loss of selfhood, for the void created by the absence of the father. Not an independent being, Bloke becomes radically dependent upon both others, a fetish-item circulating in economies both "black" and "white".

(Sanders 1994: 57)

Hence Stewart takes into account the racially overdetermined conditions (of frustrated desire) external to the cinema to which Bloke must return: "Given these conditions, we must imagine that the potential pleasures offered by the cinema extend far beyond the viewer's capacity to identify with (or resist) particular characters or ideologies or her or his ability (or refusal) to lose her- or himself within the diegesis on screen" (Stewart 2003: 661).

At another of his quietest moments, in the darkness of his Sophiatown room, Bloke's yearning for erotic circulations finds expression in the recognition of the emptiness of the promiscuous relationships, particularly the agony of loneliness after every sexual act: "there is always the anticipation and the pursuit, the excitement of climax and then, nothing" (p. 251), evidently bringing to nought what he calls "the search for a larger existence" (p. 229). Yet still he cannot stop that desire: he still has illicit fantasies about the prohibited interracial love affair with Ruth, the white daughter of his friend Dr Ellen Hellmann: 
She is sitting opposite me at table in Uncle Joe's restaurant; looking into my eyes, daring me to love her; but always I am afraid, there is only the silence. Why the screaming silence? Where is the comfort? On the ceiling of the room, through the darkness, she is smiling down at me; so near and fading into nothingness.

At this point I would like to suggest that when Bloke pines for Ruth in the darkness of his room in Sophiatown, and when he contemplates running away from his marriage in the darkness of the cinema, it becomes reasonable to suggest that his familiarity with many Hollywood films must have included the film noir genre, which, according to Bronfen (2004: 104), is a "pessimistic cinematic response to volatile social and economic conditions of the decade immediately following World War II". Given that the genre became popular in the 1950s in which Bloke Modisane's autobiography is set, and that the nature of his spectatorship involves the fantasy of betraying his wife Fiki for Ruth, there is even more credence to the suggestion that Bloke's spectatorship negotiated an identification with heroes of the genre; for "heroes of film noir repeatedly find themselves penetrating into the darkness of a fascinating, and at the same time threatening, counterworld of corruption, intrigue, betrayal and decadence from which they can only escape by death" (Bronfen 2004: 104). His escape by death, however, is vicariously represented by proxy through his father. Upon the death of his father Joseph Modisane, inscribed as William on his coffin, was born Bloke - the Simon Templar figure, "the living influence, the escape image of our frustrations" ( p. 166), after having initially expressed political sympathies for the militant ANC Youth League and then joined the even more militant Pan Africanist Congress later. The image of Bloke, redeeming as it does the "death" of William, gives expression to Modisane's earlier flirtations with Hegelian thought shortly after the birth of his daughter Chris:

The slave may be legally freed, but he shall never be emotionally and intellectually free until the symbol of his oppression shall be destroyed, as it was said that the French revolutionaries could not accept the victory of their cause until the head of the king rolled off the guillotine; it was perhaps more eloquently articulated by Hegel: "To be truly free the slave must not only break the chain; he must also shatter the image in both his and his former master's mind".

Without a victory of the freedom cause impending, Bloke shatters the image of the slave with the escape image of Bloke (putting William under erasure) or Simon Templar, or the Durango Kid figure transculturated from Tinseltown cinema into Sophiatown life. The life of this Bloke figure, replete with intrigue, fantasy and decadence, is a continuous attempt at negating death 
and negotiating erotic circulation across the colour bar as if these were inextricably intertwined, necessary but insufficient for saving either himself or Sophiatown. Acknowledging the unavailing nature of these attempts, Bloke underscores this futility first by comparing it to "the penny whistle music spinning on eternally with the same repetitive persistency" and what he calls the orgiastic rhythms of kwela music to which people in his circles "conglomerate into an incestuous society where sex becomes promiscuous and friendship explodes into murderous hatred" (p. 117). Here he poignantly paints a melodramatic scenario whereby the sexual character of self-saving, vulgarised by a meaningless circulation with many women, seems ineluctably bound to death by murder.

Makeba's music, however, is a crucial factor in her ambivalence about unqualified entry into the "outside" modernity of Tinseltown life, as opposed to Sophiatown's death. This is all the more discernible in her autobiography when she recounts that she was fast becoming a famous singer who was at her prime in the Drum decade when she went into exile, leaving South Africa's oppressive nightmare for living her teenage dream of being a big American singer like Ella Fitzgerald and Lena Horne (p. 20). Once in America, it is not fame but freedom denied that she clamours for her and those she left behind: "We have seen our best blood spilled in Sharpeville, Soweto, Crossroads. I am in exile on the outside. We are in exile on the inside" (p. 1).

Makeba's conflation of the two positions of "inside" and "outside" attests not only to another level of double consciousness concomitant with an entry to modernity, but also what Paul Smith calls a "colligation of multifarious and multiform subject positions" (1988: 32) in an autobiographical account of a musical career that is inextricably intertwined with anti-apartheid advocacy in the United States and the African diaspora. Conflation and colligation are emblematic of exits and entries into modernity that guarantee a subject position that defies being overdetermined into Sameness by stereotypes effected by the totalising history of apartheid. Thus, when Makeba precedes the statement of remembrance of collective exile in the inside with "I am in exile on the outside" (p. 1), she posits an alternative otherness that undermines apartheid censure over the otherness of the inside. Alterity, or alternative otherness, arises when the multiplicity of being one and multiple at the moment the succour of belonging is under erasure. Yet, ironically, in another key instance Bloke heightens the sense of meaninglessness and emptiness of the murderous "inside" that is Sophiatown by deploying a sexual image that turns away from the randomness of sexual objects, only to focus on one object of desire. In an opening passage worth quoting at length, he insists:

There is a Kafkan sterility in and about South Africa. Every endeavour, every action is like an orgasm in a bed of which the sheets are soiled, but there is no release of the sexual tensions; there is always the anticipation and 
the pursuit, the excitement of climax and then, nothing. All our efforts could not save Sophiatown from dying, nor all our violence wash away the blood on our hands. There were little excitements, always the promise of bigger things, but never satisfaction; like being seduced by a professional virgin, who is always hinting at promises, allowing a man to work himself into a towering desire, herself being carried along through all the stages in the sex play; then refusing, in tears, at the climax of the passion, and, feeling the man going through the agony of congestion, she will apologise for her virginity.

There is little doubt that the said professional virgin is the one unattainable woman: Ruth. As he lay in the darkness of his Sophiatown room, and in the darkness of the cinema, he loses himself to an illicit fantasy, which, at best, allows him merely to contemplate the existential dilemma of being black yet "thinking and loving white" (p. 229). His life and ontology, more precisely his "anti-death" or anti-thanatology, depends on the relationship he has with Ruth. Outside fantasy, on the streets of the South African city, real risks to his life are everywhere evident whenever he walks those streets with a white woman, ironically raising once again the spectre of death: Such an existential dilemma demands resolution:

Perhaps I was ungrateful, I should have been satisfied with the private moments of a love which was torrid in locked rooms, shut in from friends and confidants and the eyes of reproach. If I am kicked to death for my love, then it must be a love worth dying for; it must be love much bigger than the mark of infamy or disgrace, a love which will sing hallelujahs loud unto the sky.

Perhaps what Bloke yearns for is a co-functioning between himself and Ruth, black and white, man and woman, even death and life. This necessarily means that he has to negotiate a problematic temporality that, left unmanaged, could prove tragic: he could be "kicked to death in police cells" largely because Ruth feels embarrassment in the wake of disapproval, and that she is basically a white "woman who fidgets and capitulates when confronted by the scorn of her own colour" (p. 228) - invoking the danger associated with film noir's femme fatale figure. Facing as they do the eye of reproach, Bloke becomes a hero much akin to that of film noir. He enters the threatening darkness of apartheid moral corruption, all because, for one thing, he seems to have negotiated a radical spectatorship that identified him with the fantasy scenarios celebrated by film noir; for another, he gives tragic content to the aforesaid celebration, as its protagonists are fatefully entrapped in a claustrophobic world and are unable to master their destinies; and for yet another, there is Ruth as the femme fatale who, despite the forcefully professed tragic sensibility of film noir, is the very encapsulation 
of "an attitude that addresses the limits of modern dreams of perfectibility" (Bronfen 2004: 104).

Somehow Bloke's world of decadence seems to suggest that he dissipates what he calls the putridity of Sophiatown through the figure of a woman much unlike her mother or his wife - the femme fatale. In his desire for a woman who can fulfil and extend him as if they were part of a radical assemblage, we see him describing the eve of his colleague Henry Nxumalo's death as a scene that not only depicts the debauchery of a threesome but accidents which occur "accidentally on purpose" (Bronfen 2004: 105), in a manner that shows his reluctance to face noir actions: one of the two girls trips and falls on top of him, starting an orgy that would end with an admission that, in his own words, "the things for which I was looking were not all to be found in sex" (p. 265); for "it was all carnal, there was no spirituality in the relationships, even the enjoyment was mechanical, just animal enthusiasm" (p. 219). The futility of it was only matched by the death, a few hours later, of a colleague. This may well carry some symbolic significance about implenitude: this death somewhat inveighs against the exhilarating circulations of the self.

Exhilarating circulations, erotic as they come, are in a distinct sense part of losing himself in the course of saving himself from death. As suggested above, one fateful New Year's Eve, a day which was to be the eve of the death of his famous colleague Henry Nxumalo a few hours after they had been together, Bloke loses himself in a threesome, having sex as a kind of contest during which, he says, they drove their bodies "and the will to a climax whose tension was dementing the senses", and yet he admits that he became lonely afterwards, his body was "saturated with sex" and he was dissatisfied (pp. 264-265). Such circulations extended to "his search for white friendships which multiplied every week", but, as in the first case he admits again that "in the end the friendships became like the sex in my life, my wandering eyes spread promiscuously over every white person in the succession of parties" (pp. 254-255).

While Bloke bemoaned his detractors' decision to interpret his desire to lose himself as "a cowardly flight from apartheid" (p. 169), he finds that there was sanctuary in the cinema. In the darkness he could not see his black hand, much unlike in the light of day when his preoccupation is to lead a lifestyle that is like that of the silver screen or worse, as he craves acceptance in South African white society:

If Hollywood had intended to influence the development of a particular kind of person, I am the product; the tinsel morality, the repressed violence, the Technicolor dreams, these are the things I absorbed in the name of culture. They were available. The theatres discriminated against me; I am well into my thirties and have yet to see a full production of ballet or opera, even though South Africa has ballet and opera seasons to which the world's best is invited. 
Whereas there is little doubt that for Modisane popular culture is a necessary but insufficient alternative to "high culture", Stewart has shown that black spectatorship of Hollywood cinema under segregated conditions opens up the possibility of a momentary escape from the pressures and limitations of a discriminating society. More than that, it would seem to me that such spectatorship offers the kind of mobility that guarantees moving beyond mere vicarious participation. It supplements rather than sublimates desire, precisely because it signals a double temporality of reality and fantasy, black circumscription and white privilege. As a supplement, the mobility of this spectatorship affords Bloke the opportunity to enter new realms, to strike friendships across the colour bar, albeit realised as unsatisfying encounters that culminate in inhabiting spaces whose reality was mediated more by the gore of apartheid laws than by the glamour, and fluid spectatorial negotiations, of Hollywood movies. Popular culture, in a thickened temporality, supplements cultural memory.

If anything, Hollywood provided a supplement, a possibility to shift meaning to life and death under apartheid. It provided a platform for a radical spectatorship that would transculturate Hollywood figures of memory as it contemplates other archival narratives in the discursive field of ontological negotiation. Textual figures of memory arise alongside Hollywood icons, featuring a narrative process that self-reflexively controls and redirects Bloke's mobility to a nomadic crossing over into the desired circulation in the white world that rejects him:

Simon Templar was to become more than "The Saint", than infallible, that incorrigible braggart; he became, in fact, a real living influence, the escape image of our frustrations. His philosophy, his morality, persuaded itself upon us; "The Saint suited the temper of my life, served against the pangs of a discriminating society. I adopted his carefree attitudes, and behind the shell of these nothing could touch my life: not the police raids, the violence of Sophiatown, not the injustice and humiliation of being black in white South Africa"; I could defy South Africa by flashing a "Saintly" smile.

(Modisane 1963: 166)

In the case of Makeba, the storyteller selectively draws from orally established figures of memory of the struggle tradition on the one hand, and the listener-scribe continues the process by repeating the structure of a written autobiographical genre to a point where both writing and speaking are continuous textual repetitions on the margins of the elusive "truth" of experience. To receive Makeba's story hypoleptically or rewrite from the margins of his experience is to self-reflexively reinterpret it. Drawing from Deleuze, I might add that the choice involved in the self-reflexive surpassing of the discursive contours of oral expression testifies to an 
enhancement based on a writing-based woman-becoming:7 in her choice of object - a male scribe - instead of obeying the law of, perhaps, a putative black brotherhood or some other male principle, it would seem Makeba defines herself as a function of what Deleuze aptly describes as being "always at the frontier, on the border of a band or multiplicity; it is part of the latter, but is already making it pass into another multiplicity, it makes it become, it traces a line-between. This is also the 'outsider'" (1987: 42). In the same vein, tracing the line between is not merely a matter of choosing this or that multiplicity but especially "passing into another multiplicity" to become an "outsider" to official apartheid memory and history.

The Makeba international singer/anti-apartheid activist border of a multiplicity, which in a sense redeploys the ontological dilemma of being-initself and being-for-others into "Other" realms of selving, represents a cofunction of becoming that does not begin and end with Makeba in a story; rather, the border distinctly epitomises traces becomings in writing. Deleuze continues:

To write is to trace lines of flight which are not imaginary, and which one is forced to follow, because in reality writing involves us there, draws us in there. To write is to become, but has nothing to do with becoming a writer. That is to become something else .... You might say that writing by itself, when it is not official, necessarily comes into contact with "minorities" who do not necessarily write on their own account, about whom no one writes either, in the sense that they would be taken as object, but on the contrary, in which one is caught up willy-nilly, from the fact that one is writing. A minority never exists ready-made, it is only formed on lines of flight, which are also its way of advancing and attacking. There is a woman-becoming in writing.

(Deleuze \& Parnet 1987: 43)

The opportunity to write back by imploding the binary opposition between the oral and the typographic, by further using a black/white, male/female double time that acknowledges the story of Makeba's fight against apartheid has its own paradox: "Not every becoming passes through writing, but everything which becomes is an object of writing, painting or music. Everything which becomes is a pure line which ceases to represent whatever it may be" (Deleuze \& Parnet 1987: 74; my italics).

Claims to a static, centred subject are readily disabused by the self/other reconfiguration of the self simply through writing or singing as an

7. In Deleuze and Parnet, Dialogues, refusal to obey the conventional naturalised law - and I might include here the binary antagonisms that inform Makeba's struggle against apartheid - means a choice of object, a line of flight, a becoming. Deleuze proffers an example of Richard III betraying all expectations by choosing Lady Anne, thereby tracing a line of woman-becoming (Deleuze \& Parnet 1987: 42). 
"outsider" or "minority". Thus it is that, in a similar context, Bloke Modisane's becoming as the object of writing is commensurate at some point with lines of flight which map their co-functioning across figures of painting and music:

[I]n the corner of some darkened room I whisper the real desire: I want to be accepted into white society; I want to listen to Rachmaninov, to Beethoven, Bartók and Stravinski; I want to talk about drama, philosophy and social psychology; I want to look at the paintings and feel my soul touched by Lautrec, Klee and Miró; I want to find a nobler design, a larger truth of living in literature. These things are important for me, they are the enjoyment of a pleasure I want to share.

In the same vein Bloke's anticipated becoming is untrammelled by his Sophiatown setting, and desiring-production is deterritorialised by a line that passes into another trace in painting. This is evident when his mind recoils and suddenly realises the scope of the destruction to be "like a canvas by Salvador Dali, with all the despairing posture of mass desolation, then it began to look picturesque as a slum would to the tourist" (p. 33). In addition, and even more importantly, Sophiatown as a figure of memory is also received hypoleptically, through a necessary "outsider" betrayal of local specificities in an act of writing back and so willing the past into the present. It is also received through tracing lines of flight to Hollywood, especially in the sense that Sophiatown no longer exists - having been demolished as result of the injunctions of the apartheid territorial machine. Bloke therefore claims recourse to cultural memory's reconfigurative thrust of the cinematic and journalistic traditions that shaped his discursive space. At least "the letter of the law" (p. 123), a very crucial instrument of apartheid segregation, finds opposition in the self-reflexive journalistic scripts of the cultural memory of Hollywood cinema. In this selective repetition of Hollywood, in the very act of writing, the return to the scene of local popular culture is simultaneous with advancing, outward-bound lines of flight that, according to Zodwa Motsa, confirm "that there is a high degree of integration between the writer's art, life and politics" (2009: 10). Significantly, throughout Blame Me on History, Bloke makes references to Hollywood films, for example, utters bold statements here and there about "a virtue I learned from Hollywood films" (p. 261). There may not be a clear pattern of inscribing his woman-becoming, yet there is the sympathetic connection with women, received hypoleptically through Hollywood as well as his father's exhortations to self-control after his sister Nancy's death, upon the event of whose funeral he confides that he "would have most probably disgraced my masculinity" (p. 19) by crying like his bereaved mother. It is an interesting irony that he chooses writing, becoming-woman, to obviate such a disgrace. For inasmuch as Bloke 
laments the emptiness of the "overlay of sex" (p. 211) in his numerous conquests, he rationalises it as obsession "with the need to express something in me" (p. 210), desiring as he does "a woman who could look deep into beauty and hard at ugliness, who could feel a hurt and an injustice suffered by Others as if it were her own" (p. 218).

That peculiar "something" in him demands that he should direct his energy to writing,

determined to use it as the weapon for gate-crashing into worlds that rejected me; my writing showed a studied omission of commitment, the histrionics of tight-fisted protest, and in my first published short story, The Dignity of Begging ... I projected myself into the character Nathaniel Mokgomare, an educated African capable in any society of earning a living, but handicapped by being black in a society which has determined that black is the condition of being dependent on white charity .... To the handicap of being black I added physical deformity, investing my character with a kind of double indemnity, then confronted him with the realisation of his condition.

This figure, for Bloke, is indicative of one way of surviving, of cheating death. Yet, essentially he had to write in order to obviate a repetition of death. An event that highlights his woman-becoming happens when he associates, clearly by choice, another child's funeral with his sister Nancy:

I switched off the memory machine, but there was another kind of death gaping at me; I turned away from the ruins of the house where I was born in a determination not to look upon this death of Sophiatown. I removed my hat and stood still while a modest funeral train drove past; it was an open lorry carrying a small white coffin and not more than a dozen people. Another child victim, another Nancy.

Another choice, one might add, is of a girl-child whose memory cannot be completely shut off. Another woman-becoming is hereby revealed. Later on when his mother impresses upon him his new role as the father figure and shield of the family (p. 28) he still imagines death by comparison to Nancy's for it to register its impact in his life. Life and death, man and woman, past and present, individual and community are all inextricably caught up in a co-functioning whose indeterminacy can only be understood in terms of the double time of representation, the co-function of an assemblage, continuing as it does into continuous lines of becoming: Bloke, like Makeba, exhibits the mutual necessity of writing to orality, and of woman to man, black to white in a bloc of becoming, especially because it "is not that the two are exchanged, for they are not exchanged at all, but the one becomes the other if the other becomes something yet other, and if the terms disappear" (Deleuze \& Parnet 1987: 73). 
The death upon death - of Sophiatown and his father - allows him to adopt a different anti-thonological perspective to life, particularly at the birth of his daughter Chris, and memoric rebirth of Sophiatown, amongst others. For example, at the very outset Modisane describes Sophiatown as a piece of him that died, as being "like one of its own many victims; a man gored by the knives of Sophiatown", an image that invokes "the look of shock and bewilderment, of horror and incredulity" (p. 5). Yet he does not find it objectionable to watch cowboy films which were "always the same blood and thunder tupenny horrors with memorable titles like Two Guns West, The Fastest Gun Alive, Guns over the Prairie" (p. 6), only to describe his own near-death experience in the Odin Cinema in terms of Hollywood films: Lelinka, the loud gangster who will not be told to be quiet in the cinema, points a gun at Bloke while the film is running (pp. 7-8).

Modisane's archive is therefore replete with Hollywood motifs that not only constitute the bane of journalistic stories for the Golden City Post weekly tabloid. Beyond his memory of stories of self-styled cowboys such as Durango Kid, the connection and co-functioning of the cowboy in film and the cowboy in real life extends, by some self-reflexive selection, into the articulation of his subjectivity in the representational time that is both outside and inside Sophiatown, within and without the journalistic tradition. Yet this may be read, as Jacqueline Stewart (2003: 650-677) has done in the African American context of black spectatorship, to "exemplify unsophisticated black spectators who uncritically enjoy Hollywood cinema despite the films' illusionist incongruity with the 'realities' of their lives". Stewart here examines characters in Richard Wright's Native Son (1940) and Toni Morrison's Bluest Eye (1970) as subjects of an oppressive social map that predisposes them to the alienating "glitter" of classical Hollywood Cinema, which could be (mis)understood to be "a medium of absorption and distraction (Stewart 2003: 658). The difference is that in Blame Me on History, cinema, specifically the cowboy Western genre, spectatorship involved a degree of negotiating the signifying time of popular culture, of transculturation and negotiation of "outside" identities and spaces, where Sophiatown's children and noise get caught up in a Hollywood-becoming:

A fraction of the noise rearranged itself into a children's fantasy, they were the hero of the film, The Fastest Gun Alive, each in his turn was Broderick Crawford, and in their mouths the name, Broderick, was blown into gigantic proportions; they invested the name with the image of the classical hero ... They paced back away from each other, their shooting hands hovering over the imaginary gun in the imaginary holster, poised for the draw; the gun fighters stopped, measured each other, each searching that nervous muscular twitch in the face, and, in the idiom of Westerns, for one of them it was going to be the last sunset; then they moved forward with the stereotype slow deliberateness, and stopped. "My name is Broderick, the fastest gun there is," one said. 
It may seem escapist, the ordinary world of children playing cowboys until a friend, William Dumba, somewhat ominously declares: "That's how they start .... Tomorrow they will be shooting real guns" (p. 52). They are telling a story that is without innocence, not confined to Odin cinema, but reflecting the public drama of South Africa: "The mud pool was the Wild West of America or the dark interior of Africa; and to us, out there in the pool, the white boys were the Red Indians, and we were the cowboys" (p. 17). Following Miriam Hansen, Stewart asserts that "the public dimension of cinematic reception" can give rise to "formations not necessarily anticipated in the context of production" (2003: 661).

Similarly, as Makeba and Bloke Modisane tell their life stories, the autobiographical narrative becomes a site of sympathetic co-functioning where intersubjectivity is born of a double articulation of the memoric voice and the transculturating pen. Across their race and gender, Makeba and Modisane are in no conventional conversation between an autobiographical subject and a reader-cum-interlocutor. We have here a writing moment in an assemblage marked by discursive migrancy whereby the visual signs of popular culture, the vocal chords of cultural memory and orthographic signs of self-writing straddle "the dialectical space between two subjectpositions" and render visible not merely the details of Modisane's life but also the mediating process of representation through a conscious act of "speaking with" Modisane as opposed to "speaking for" him (Arnott 1996: 87).

Differential subject positions relative to Makeba and Modisane underscore an awareness and enhancement of the "plebeianized" process of multiplicitous representation of textual subjectivity. What seems clear is that the repetitions of the "l" through "others" gives evidence to the doubt necessary, the double temporality, for the reconstitutive thrust of cultural memory: in becoming two subjects there is "demographic plebeianization" of subjectivity as "we experience the body through our experience of the world and of other people" (Jameson 2003: 710). In other words, there is a multiplicity that corresponds with a "thickened" (at least double) temporality. For the representation of figures of memory is in itself a function of difference. Those important events of Modisane's life accrue their significance on the basis of difference from others left out of the memoric archive. Furthermore, the three poles of narrativised expression of Modisane's suffering, growth, redemption and becoming hold the memoric record in counterpoise. An avowed self-representation that assumes unmediated self-knowledge is therefore obviated. In relation to the aforementioned mediation, Spivak puts forth an interesting formulation that the occluded distinction between autobiography and testimony attests to postcolonialism's management of the crisis of postcoloniality, from which position she proceeds to draw specific attention to the psychoanalytic situation of testimony: "Testimony is the genre of the subaltern giving witness to oppression, to a less oppressed other" (Spivak 1998: 8). 


\section{$J L S / T L W$}

Within such a formulation of testimony, the stories of Makeba and Modisane are mediated in a popular culture that bears witness "with" the spectator. This expands not only temporality but agential identity: it posits "otherness" vis-à-vis the discursive regime that excludes blackness from any form of subjectivity. For example, Makeba's life (bios) to be writable (graphe), the "l" (auto) has to be "doubled" in the oral rendition's concomitant prospect of testimonial writing. Arrival at that "double", that repetition across forms, requires a distancing from everyday memory. The repetitive doubling of popular culture and figures of memory therefore extends beyond the mediation across the oral and the written but also continues when the autobiographical subject becomes "the assuming subject assuming object" at the very moment $\mathrm{s} /$ he gives witness to his truth. Such an assumption is the co-function of the witness-as-spectator, bystander-asagent, and cultural memory as problematised popular culture.

A Hollywood/Sophiatown co-function, however, becomes more apparent in a production of a borderline repetition in Modisane's life when he describes the event surrounding his daughter's birth, when he

was pacing outside the room, like the Hollywood cliché of the nervous husband, but I was not in a film and Fiki was not being delivered in antiseptic Hollywood wards, she was in a rooming-house in Sophiatown, in a yard littered by dogs, by the droppings of pigeons and fowl, spiced with skokiaan fumes and the smells of the outdoor lavatory, the community centre which was impossible to keep sanitary ... yet I could not resist miming the histrionics of the anxious white husband, as parodied - I hope - in Hollywood films; I was pacing in front of the door, affectedly nervous, chain smoking, stopping, listening, continuing the marathon, all to the delight and amusement of young brother Pancho and Suzan.

(p. 71; my italics)

Bloke's borderline script draws on a Hollywood archive in order to repeat the borderline margins of Sophiatown beyond their parodic repetition on film. The exergue of a parodic repetition of Hollywood testifies to what Spivak earlier on identifies in autobiography as "I and me, assumed subject assuming object. The intention of the 'subject' is to objectify itself without loss of subjectship" (Spivak 1998: 7). Inasmuch as Modisane and Makeba are in a textual process of giving witness to the struggle by rewriting in English a professed fight against apartheid, in Blame Me on History there is a heightened kind of transculturation of English language, journalistic tradition and Hollywood figures of memory. While following Stewart's developed notion of reconstructive spectatorship based on "fluidity, negotiation, heterogeneity, and polyphony" (2003: 660), I will endorse Rob Nixon's observation that

Hollywood offered a mixture of transport and recognition; a reprieve from apartheid's suffocating prohibitions but also entry into a world of celluloid gangsters that could confirm and inspire South Africa's criminalized non- 
citizenry in their shadow lives beyond the pale; the synthetic allure of Hollywood's crepuscular glitter pervaded Sophiatown culture.

(Nixon in Manzo 1995: 120)8

Certainly Hollywood does not overdetermine the articulation of subjectivities but rather becomes a site which is negotiated in its repetition, reconfigured in its recognition, and transculturated in cultural memory.

According to Manzo (1995: 120), Rob Nixon's consideration of transculturation and cultural exchange between South Africa and the United

States is established across "imaginative common ground" and "loose affinities". To "write" Hollywood, therefore, is to frame an assemblage within which fluid and polyphonic becoming is possible. In Modisane's and Makeba's polyphonic writing of a multiplicitous assemblage of a cofunction of Hollywood and Sophiatown there is evidence of what Masemola designates as an uncanny "(dis)continuity of fixed affiliations", of unproblematic identification and mimetic repetition of figures of memory:

"Repetition here is neither positive nor negative but situated in between two discursive formations and, as such, located on the edge of both" (Masemola 2010: 116; my italics).

There is a sympathetic co-functioning between Tinseltown and Sophiatown that allows for an inscription that affirms becoming a multiple subject that is a life force to be reckoned with, not merely recognisable as belonging to Tinseltown or the Black Atlantic assemblage. For example, Modisane, like Jacques Derrida elsewhere, becomes "the living and the living feminine", thereby surviving "the named autobiographical subject already dead in patronymic or, as Nietzsche writes, 'as my father I am already dead'" (quoted in Spivak 1998: 13).

It is very interesting that Spivak (1998: 13) draws attention to the fact that Derrida as a bereaved son, "in half-mourning [demi-deuil] finds his patronym encrypted"; for William Bloke Modisane, it takes his father's funeral service to reveal him as a subject already dead in patronymic:

The bearers carried the coffin out of the house, the yard, and into the hearse, and as they passed I noticed that "William Modisane" had been inscribed on it in error. The shock of seeing my name and not my father's confused and frightened me, but it seemed symbolic somehow; I was officially dead, something I was later to exploit emotionally.

This marks Bloke's anti-thonological rebirth, his will to reposition himself for entry, into circulations of becoming, culminating in his anticipated final

8. This passage is central to the review of Nixon's Homelands, Harlem and Hollywood: South African Culture and the World Beyond (London: Routledge), in Kate Manzo's "The National Question: South African Identities at Home and Abroad," in Transition (1995), Issue 68, pp. 116-132. 
migrancy into exile, the place from which, as he puts it,"Ezekiel Mphahlele had been writing me sane letters which implied that he was on the road to a human recovery, the letters contained a happiness which we had failed to realise even in our most riotous moments during those promiscuous white parties" (p. 250). Ironically, this is the exile of resolving the existential dilemma through African humanism and the gruesome death of a son in Mphahlele's The Wanderers (1973). Mphahlele's humanism was a response, a sum of existential acts of Being-for-Itself, in-Itself and for-Others in a process that demanded becoming rather than belonging in the African diaspora. Mphahlele found himself in the double temporality of reverie and history in order to articulate the difficulty of belonging and the existential imperative of becoming. For Bloke the darkness of cinema provided the space of resolving his non-belonging in both white and black society in South Africa. That darkness, doubly resonant with the darkness of his room in which illicit fantasies are played out, is the exergue of the exergue, the margin of the margin, from where his discursive migrancy from Sophiatown to Tinseltown makes for selfing and becoming. It is also the mise en scène of the pain of vain bodiographic experience of sexual excitement as he circulates in black and white worlds of Sophiatown rather than the agential space of Tinseltown's popular culture.

The signifying time is thus double, taking its impetus of darkness from the reaction to his father's death. Its anti-thanatological thrust derives in the very act of remembering, retelling and writing across different natures in a co-functioning that makes the signification of the autobiographical "I" possible and public. There is no denying that the entry of black people into public discourse comes by way of a form of reconstructive spectatorship that would characteristically draw on fluidity and heterogeneity, and polyphony suggested by Stewart (2003: 660). I should add that intersubjectivity and intertextuality are crucial in the said thrust; for untrammelled circulation in other worlds - be they of white South Africa, the African diaspora or the Black Atlantic - are marked by divided, if multiple, subjectivities as well as the double archive of written canons and cinematic archives.

In Makeba's case, the construction of temporality and historicity of remembrance are publicly marked out by an intersubjectivity and intertextuality partly modelled on - and mostly gleaned from - Hollywood's

figures, especially for the construction of the polyphony of cultural memory. Ultimately the winner of Grammy Awards with Harry Belafonte in 1966, in the cultural memory of her autobiography Makeba is as much enthralled by Ella Fitzgerald and Lena Horne up on the cinema screen as she is moved by the intricate music and dance of the Bapedi in Johannesburg: "The Bapedi stomp and sing out in the field, and there I am, on the edge, singing with them, apart from them but sharing their joy" (p. 15; my italics). This edge is the exergue of the borderline text. It repeats itself in the in-between space across which reconstructive spectatorship of Hollywood becomes instru- 
mental in the multiple construction of autobiographical self-affirmation. In these circumstances, the Being-in-Itself clearly assumes an unstable identity of the edge of the Hollywood text. Dissolved in a connected assemblage identity of becoming rather belonging to the Bapedi, Being-in-Itself is what exists beyond the self, yet "the undifferentiation of the in-itself is beyond an infinity of self-affirmations, inasmuch as there is an infinity of modes of self-affirming" (Sartre 1956: 28).

If, as I have argued, there is more of becoming than vicarious participation in two worlds, here then is yet again a situation where the memoric archive of autobiographical intertextuality straddles two temporalities captured in the mode of actuality. On and off the screen, the many faces of Hollywood in popular culture are both traces of cultural memory and an affirmation of the self within an assemblage. As Deleuze and Parnet (1987: 79) make clear: "Assemblages - in their content - are populated by becomings and intensities, by intensive circulations, by various multiplicities". The contemporary context negotiates the objectivised meaning of heterogenous selfaffirmation in a double perspective such that the black and white world governed by a Manichean dynamic or race is dissipated by the Hollywood technicolour of which Bloke waxes lyrical, and in which Makeba campaigns for non-racial democracy. Thus, in sum, the construction of the double signifying time of cultural memory of autobiographies by Modisane and Makeba is distinctive in its association with Hollywood and, at the same time, disjunctive in its outward-bound lines of flight. Repetitions of Tinseltown figures in Sophiatown and beyond attest to aspects of illicit desire as in film noir, enacted bodiographically between the two locales through lines of flight that mark the intensive circulations of the body in black and white worlds, in what Bloke - following Nimrod Mkele - calls birds-of-passage morality (p. 207). Double temporality, therefore, is as much at the heart of becoming as Hollywood is part of a bloc of becoming. Combinations of fluxes that underscore blocs of becoming circulate the discursive circuit of Tinseltown and Sophiatown, the Black Atlantic archive and its exergue, the black and white dynamic of double consciousness, and the double temporality of a bodiographic articulation of demographic plebeianisation through what Spivak (1998: 7) calls the "I and me" of autobiography or, alternately, "the subject assuming object".

\section{References}

Arnott, Jill 1996. French Feminism in a South African Frame?: Gayatri Spivak and the Problem of "Representation" in South African Feminism. In:

Daymond, Margaret (ed.) South African Feminisms. New York \& London: Garland, pp. 77-89. 
Assman, Jan 1995. Collective Memory and Cultural Identity. New German Critique 65:125134.

Bronfen, Elisabeth 2004. Femme Fatale: Negotiations of Tragic Desire. New Literary History:Multicultural Essays 35(1): 103-116.

Deleuze, Gilles \& Parnet, Claire 1987. Dialogues, translated by Hugh Tomlinson \& Barbara Haberjam. NewYork: Columbia University Press.

Gilroy, Paul 1993. The Black Atlantic: Modernity and Double Consciousness. London:Verso.

Jameson, Fredric 2003. The End of Temporality. Critical Inquiry 29(4): 695-718.

Makeba, Miriam (with James Hall)1988. Makeba: My Story. London: Bloomsbury.

Manzo, Kate 1995. The National Questions: South African Identities at Home and Abroad. Transition 68: 116-132.

Masemola, Kgomotso Michael 2010. The Individual Collective Utterance: Lack, Law and Desire in the Autobiographies of Ellen Kuzwayo and Sindiwe Magona. Journal of Literary Studies/Tydskrif vir literatuurwetenskap 26(1): 111-134.

Modisane, William Bloke 1963. Blame Me on History. London: Thames \& Hudson.

Motsa, Zodwa 2009. Autobiography or Epic?: Long Walk to Freedom and the

Mutating Face of the Epic. Journal of Literary Studies/Tydskrif vir literatuurwetenskap 25(2): 7-24.

Nkosi, Lewis 1964. The Sting in the Adder's Tail. Transition 12(Jan-Feb): 54-55.

Nuttall, Sarah 2002. Bodiographies: Writing the Body in Arthur Nortje. WISER Series (August Issue): 1-27.

Raditlhalo, Sam 2009. The Self-Invention of Hugh Masekela. Journal of Literary Studies/ Tydskrif vir literatuurwetenskap 25(1): 34-52.

Sanders, Mark1994. Responding to the "Situation" of Modisane's Blame Me on History: Towards an Ethics of Reading in South Africa. Research in African Literatures 25(4): 51-67.

Sartre, Jean-Paul 1957. Transcendence of the Ego: An Existentialist Theory of Consciousness, translated by Forrest Williams \& Robert Kirkpatrick. New York: Noonday.

Smit, Paul 1998. Discerning the Subject. Minneapolis: University of Minnesota Press. Spivak, Gayatri 1998. Three Women's Texts and Circumfession. In: Hornung, Alfred \& 
BETWEEN TINSELTOWN AND SOPHIATOWN: THE DOUBLE TEMPORALITY ...

Ruhe, Ernstpeter (eds) Postcolonialism and Autobiography. Amsterdam \& Atlanta, pp. 7-22.

Stewart, Jacqueline 2003. Negroes Laughing at Themselves?: Black Spectatorship and the Performance of Modernity. Critical Inquiry 29(4): 650-677.

Kgomotso Michael Masemola

North-West University, Mafikeng Campus

Kgomotso.Masemola@nwu.ac.za 